\title{
References:
}

1. Lysenkov, S. L. (1997). Konstytuciya Ukrayiny: Materialy do vyvchennya [Constitution of Ukraine: materials for study]. Kyiv: Lybid, p. 95.

2. Petryshyn, O., \& Serogina, S. (2009). Zmishana respublikanska forma derzhavnogo pravlinnya: pytannya teoriyi ta praktyky [Mixed republican form of government: questions theory and practice]. Law of Ukraine, no. 10, pp. 57-60.

3. Bostan, S. K. (2017). Forma pravlinnya suchasnoyi derzhavy: problemy istoriyi, teoriyi. praktyky [Form of government of the modern state: problems of history, theory, practice]. Zaporizhya: Law institute, pp. 121-122.

\section{THE QUESTIONS OF ASSESSMENT OF THE COST OF SERVICES AT CARRYING OUT COMMODITY EXAMINATIONS}

\section{Inna Sabadash ${ }^{1}$}

DOI: https://doi.org/10.30525/978-9934-588-84-6-14

Development of new directions in the performance of various types of examinations and expert research is one of the priority areas of scientific activity of specialists of state specialized forensic institutions of the Ministry of Justice of Ukraine. One of the problematic issues that arises at the present stage of development of forensic examination is to determine the cost of services. When conducting commodity research to determine the cost of services, within the expert specialty «Determining the cost of machinery, equipment, raw materials and consumer goods», there is a lot of controversy and doubt both among forensic experts working in state expert institutions and among appraisers. This is due to the fact that the service is a product that is immeasurable and intangible. Also one of the arguments is that the word "service» is not included in the name of the specialty and does not refer to the objects of assessment in intangible form, according to the definitions of the national standard № 1 «General principles of property valuation and property rights», which sets out the definition of Intangible assets - objects of valuation that do not exist in tangible form, but allow to obtain certain economic benefits. Objects in intangible form include financial interests (shares, stocks, shares, options,

\footnotetext{
${ }^{1}$ Kharkiv Research Institute of Forensic Examinations of the Ministry of Justice of Ukraine, Ukraine
} 
other securities and their derivatives, promissory notes, receivables and payables, etc.), as well as other property rights.

It should be noted that the end result of work for the provision of any service is evaluated in monetary terms, the service is a kind of product, proposals for the provision of which are on the market of Ukraine, and accordingly may be subject to evaluation. In our opinion, this point of view is relevant, in this regard, at the meetings of the section of forensic examination of the Scientific Advisory and Methodological Council on Forensic Science at the Ministry of Justice of Ukraine it was noted that the problem of methodological regulation to address the cost of services resolved.

Currently, there are no methods and methodological recommendations for the preparation of materials for forensic examinations to assess the cost of services, in this regard, we consider it necessary to conduct research that will contribute to the formation of common methodological principles, as well as the correct formulation of expertise and expert research in this area.

In connection with the above, the Volyn branch of the Lviv Research Institute of Forensic Examinations of the Ministry of Justice of Ukraine is currently conducting research on «Determining the cost of services in conducting forensic examinations». The co-executor of the topic is the Hon. Prof. M. S. Bokarius Kharkiv Research Institute of Forensic Examinations of the Ministry of Justice of Ukraine. Creating guidelines on this basis will ensure the objectivity and completeness of research.

In addition, the classification will be carried out and the range of services will be determined, the limits of competence of commodity experts will be determined (what types of services can be the objects of commodity examinations and expert research), the list of initial data necessary for determining the cost of services will be formed.

Summing up, we conclude that the creation of guidelines «Determining the cost of services during forensic examinations» will help:

- ensuring the objectivity and completeness of the study to determine the cost of services;

- formation of uniform methodological bases at carrying out of examinations and expert researches of the given direction;

- in the future use by law enforcement agencies and judges of the results obtained for the preparation and appointment of forensic examinations, as well as the correct formulation of issues raised in cases of determining the cost of services; 
- elimination of gaps in determining the cost of services, which will be based on the study of regulations, special literature in this field and the practical experience of experts;

- use for training and confirmation of qualification of forensic experts in the relevant specialty.

\section{APPROACHES TO THE DEFINITION OF THE CONCEPT «AGRICULTURAL COOPERATION», ITS ESSENCE AND SIGNS}

\section{Oleksandra Khrishcheva ${ }^{1}$ Viktor Masin $^{2}$}

DOI: https://doi.org/10.30525/978-9934-588-84-6-15

The concept of «agricultural cooperation», which is special in relation to the category of "cooperation», should contain general signs of cooperation and, at the same time, reflect the specifics of agriculture.

Agricultural cooperation is the most important factor of the sustainable development of rural areas, as it is a link between measures of state influence on the social development of the village and the villagers with their traditions, skills and aspirations. It is also important to take into account the geopolitical importance of agricultural cooperation, which should play its role in preserving the population in rural areas and preventing the decline of certain regions of the country.

To date, there is no consensus among scientists on the definition of agricultural cooperation. Consider the main approaches to explaining the essence of agricultural cooperation.

S. L. Maslov was an outstanding theorist of agricultural cooperation. He saw the socio-economic mission of cooperation in the village in protecting the interests of the peasant from the exploitation of intermediary traders [4, p. 48].

O. Chayanov understood agricultural cooperation as a «union of farms», which are not destroyed by this, but continue to remain small farms and receive a corresponding profit $[3$, p. 6].

\footnotetext{
${ }^{1}$ I. I. Mechnikov National University, Ukraine

${ }^{2}$ I. I. Mechnikov National University, Ukraine
} 